\title{
Institutional care for children and adolescents that use drugs
}

\author{
Cuidado institucional a crianças e adolescentes usuários de drogas
}

\author{
Julia Corrêa GOMES ${ }^{1}$ iD) 0000-0002-4982-3003 \\ Fernanda Kimie Tavares MISHIMA-GOMES ${ }^{2}$ (iD) 0000-0003-1731-149X \\ Clarissa Mendonça CORRADI-WEBSTER ${ }^{2}$ ID 0000-0002-3386-1267
}

\begin{abstract}
The literature highlights the existence of weaknesses in the psychosocial care network, especially in the treatment of children and adolescents that use drugs. The study aimed to comprehend, based on the Winnicottian theoretical framework, how a Residential Care Unit has been providing care to children and adolescents with needs arising from drugs use in situations of social vulnerability. Semi-structured interviews, with eight care providers, and 65 hours of participant observation were carried out. From the thematic analysis, three themes were constructed: (1) Setting: regarding attention to basic needs and construction of a routine; (2) View: regarding empathy and expansion of perspectives; (3) Aggressiveness: regarding new ways of relating. Important actions are aimed at constructing care for this specific population, as this is a current theme with recent and weakly structured public policies.
\end{abstract}

Keywords: Mental health services; Social vulnerability; Substance abuse treatment centers; Substance-related disorders.

\section{Resumo}

A literatura aponta para a existência de fragilidades na rede de atenção psicossocial, sobretudo, no tratamento de crianças e de adolescentes usuários de drogas. Este estudo teve como objetivo compreender, a partir do referencial teórico winnicottiano, como uma Unidade de Acolhimento infantojuvenil vem oferecendo cuidado a crianças e a adolescentes com necessidades decorrentes do uso de drogas e em situação de vulnerabilidade social. Foram realizadas entrevistas semiestruturadas com oito profissionais e 65 horas de observação participante. A partir da análise temática foram

1 Universidade de São Paulo, Faculdade de Filosofia, Ciências e Letras de Ribeirão Preto, Programa de Pós-Graduação em Psicologia. Ribeirão Preto, SP, Brasil.

2 Universidade de São Paulo, Faculdade de Filosofia, Ciências e Letras de Ribeirão Preto, Departamento de Psicologia. Av. Bandeirantes, 3900, Monte Alegre, 14040-901, Ribeirão Preto, SP, Brasil. Correspondence to: C.M. CORRADI-WEBSTER. E-mail: <clarissac@usp.br>. Support: Fundação de Amparo à Pesquisa do Estado de São Paulo (Process no 2017/11869-9).

Article based on the dissertation of J.C. GOMES, entitled "Articulação do cuidado a crianças e adolescentes usuários de drogas: estudo de caso em uma unidade de acolhimento". Universidade de São Paulo, 2019.

How to cite this article

Gomes, J. C., Mishima-Gomes, F. K. T., \& Corradi-Webster, C. M. (2021). Institutional care for children and adolescents that use drugs. Estudos de Psicologia (Campinas), 38, e190140. https://doi.org/10.1590/1982-0275202138e190140
} 
construidos três temas: (1)Ambiente: sobre atenção às necessidades básicas e construção de rotina; (2) Olhar: sobre empatia e ampliação de perspectivas; (3) Agressividade: sobre novas formas de se relacionar. São discutidas ações que visam à construção do cuidado para essa população específica já que essa é uma temática atual com políticas públicas recentes e fragilmente estruturadas.

Palavras-chave: Serviços de saúde mental; Vulnerabilidade social; Centros de tratamento de abuso de substâncias; Transtornos relacionados ao uso de substâncias.

According to the $3^{\text {rd }}$ National Survey on Drug Use by the Brazilian Population, approximately 145 thousand adolescents aged 12 to 17 years were considered dependent on alcohol or some other substance, not including tobacco, and 38 thousand were considered to have been dependent on some illegal substance in the previous 12 months, with a mean age at first use of 13.1 years (Bastos, Vasconcellos, Boni, Reis, \& Coutinho, 2017). International studies suggest that services that offer specific care for children and adolescents that use drugs, need to have a low threshold, provide 24-hours care and have empathic (non-critical) care providers, providing education on the benefits of treatment and involving the young people in the decision-making process (Dunne, Bishop, Avery, \& Darcy, 2017; Russell et al., 2019).

One of the current challenges for the Rede de Atenção Psicossocial (RAPS, Psychosocial Care Network) refers to the care provided to children and adolescents that use drugs. The service, depending on the municipality's organization, is provided by the Centro de Atenção Psicossocial infantil (CAPSi, Child Psychosocial Care Center) or Centro de Atenção Psicossocial álcool e drogas (CAPSad, Alcohol and Drugs Psychosocial Care Center). However, there are difficulties related to the limitations of these services. The CAPSi has difficulties in meeting demands related to drug use, and CAPSad may present little adequacy and difficult access for the child and adolescent population due to not considering the specificities of this age group (Conceição, Andreoli, Esperidião, \& Santos, 2018). The RAPS is characterized as being a set of health and mental health services that, articulated in levels of increasing complexity, provide actions that seek to guarantee the integration of the health care. One of the components of the RAPS is the Atenção Residencial de Caráter Transitório (Residential Care of a Transitional Nature) in which the Unidades de Acolhimento (UA, Residential Care Units) are located (Ministério da Saúde, 2011).

The Residential Care Units were instituted by Law $n^{\circ} 121 / 12$ and are accessed through referrals from the Centro de Atenção Psicossocial (CAPS, Psychosocial Care Center) (providing temporary and voluntary residential care for up to six months to people in situations of social vulnerability, with needs arising from drug use. They are divided into services aimed at attending the adult as Unidade de Acolhimento Adulto (UAA, Adult Residential Care Unit) and child and youth as Unidade de Acolhimento infantojuvenil (UAi, Children and Adolescents Residential Care Unit) public, being alternatives to admission to private clinics and therapeutic communities. The UAi serves a public aged 10 to 18 years of both sexes, considering in the individual therapeutic project, humanized care, social reintegration, family bonds and links with the network, among other aspects (Ministério da Saúde, 2012). Due to their recent implementation and reduced qualification of the UAis, young drug users were being attended or interned in institutions aimed at adults, as is the case of CAPSad, or religious organizations, such as some Therapeutic Communities (Jimenez, Adorno, \& Marques, 2018). Therefore, the UAi has the potential to provide assistance in the territory, focused on the specific needs of this age group, fulfilling an institutional role that could provide resources for this population.

The importance of environmental provision was highlighted by Winnicott, who, when studying intra-family relationships, emphasized that the environment can facilitate or damage the emotional development of the individuals. He described three fundamental processes for the emotional maturation 2 process to take place: holding, handling and object presenting (Winnicott, 1964/1994). Winnicott (1963/1983, 
p.80, own translation) ${ }^{3}$ pointed out that "in this language health means both the health of the individual and the health of society, and full maturity of the individual is not possible in the immature or ill social setting", particularly emphasizing that there are three environments in the life of the baby: the first being the maternal figure, followed by school and society. If the child/adolescent has psychological distress, it can appear in the relation to any of these settings (family, school or social), and the provision of care and emotional support in different areas is possible in these interactions (Mishima-Gomes, Dezan, \& Barbieri, 2014), which indicates a sign of hope in the continuity of the individual's emotional development.

In the initial relationship with the provider figure, if the care was good enough, the individual feels safe, self-confident and able to relate socially. If the relationship with the baby's first setting is unfavorable for its emotional development, that is, permeated by intense and intrusive failures, insecurity, fear and affective deficiency become present. As a means of filling this gap and appeasing the anguish, the individual can seek a relationship with the social setting that is based on having and consuming, that is, through addictive behaviors, such as overeating or drug use (Mishima-Gomes, 2011; Zimerman, 2009). Chinalia, Assis, Visintin, and Aiello-Vaisberg (2018) highlighted that it is valid to expand the notion of setting beyond the family relationships, considering the social, historical, economic and cultural contexts, especially given the marked socioeconomic inequality in Brazil. It is important to emphasize that, if the individual has not had sufficiently good experiences with the maternal figure, freezing their emotional development, it is still possible that other settings are able to provide emotional provision, such as the school or the social environment (Andrade, Mishima-Gomes, \& Barbieri, 2018).

Considering the need to construct spaces that adequately fulfill the requirements of children and adolescents that use drugs, this study aimed to comprehend, based on a Winnicottian theoretical framework, how a residential care unit in the state of São Paulo has been providing care to children and adolescents with needs arising from drug use in situations of social and family vulnerability.

\section{Method}

This was a qualitative and exploratory study, carried out in a UAi, located in the state of São Paulo. The service is divided into two complementary residences that provide care for children and adolescents. They are located in the central region of the municipality, with the same team of 15 care providers: a coordinator, two psychologists, two social educators, a cleaner, a cook and eight monitors who take turns to remain in pairs, providing a 24-hours service. The UAi was founded in 2014, is accessed through referral from the Centro de Atenção Psicossocial Infantil Álcool e outras Drogas (CAPSiAD, Child Psychosocial Care Center for alcohol and other drugs) and operates 24 hours a day, seven days a week, with 10 places for temporary transitional housing for children and adolescents with needs arising of drug use (Ministério da Saúde, 2012). When implemented, it operated in a building that was a former asylum and retirement home, with an institutional profile. It was attended by many professionals and young people. Therefore, the care providers assessed that the space was not adequate and two other houses were rented: a house with residential characteristics, for the 24-hours reception of young people; and another house for bureaucratic and therapeutic activities (workshops, individual consultations, psychopedagogy activities and therapeutic groups) provided for children and adolescents at risk and for their family members, with opening hours from $8 a m$ to $5 \mathrm{pm}$, Monday to Friday.

\footnotetext{
$\boldsymbol{\nabla} \boldsymbol{\nabla} \boldsymbol{V}$
}

$\mathbf{3}$ In original: "normalidade significa tanta saúde do indivíduo como da sociedade, e a maturidade completa do indivíduo não é possível no ambiente social imaturo e doente" (Winnicott,1963/1983, p.80). 


\section{Participants}

Eight UAi care providers participated in the study, selected according to the variability of the functions performed and their proximity with the care for the users. In order to preserve their identities, they will be identified with fictitious names as described in Table 1.

Table 1

Characterization of Participants. Municipality of the state of São Paulo (SP), 2018

\begin{tabular}{llccc}
\hline Participant & Sex & Education & Weekly workload & Length of service \\
\hline Helena & Female & Complete Higher Education & 30 hrs & 6 years \\
Maria & Female & Complete Higher Education & 40 hrs & 4 years \\
Vitória & Female & Incomplete Elementary Education & $12 / 36 h r s$ & 2 years \\
Fernanda & Female & Complete High School Education & 40 hrs & 2 years \\
Sandra & Female & Complete Higher Education & 30 hrs & 4 years \\
Sofia & Female & Complete Higher Education & 40 hrs & 6 years \\
Simone & Female & Complete Higher Education & 30 hrs & 3 years \\
Rafael & Male & Complete Higher Education & 40hrs & 5 years \\
\hline
\end{tabular}

\section{Instruments}

Semi-structured interviews and a field diary were used. The interviews addressed the care providers' concepts regarding the practices developed in the UAi, among them, the activities performed, advances and impasses faced in the routine, strategies used to provide a humanized welcome, socialization, family integration, social reintegration, articulation with the network, difficulties encountered and possible improvements. The field diary was used throughout the research process, in which data from the participant observations were recorded, which contributed to comprehend the context of the institution.

\section{Procedures}

Data collection was carried out in the two residences that compose the UAi. The researcher followed the service routine and the performance of the workshops and activities developed by the technical professionals, through participant observation. In total, 65 hours of participant observation were carried out, divided into different periods and days of the week over the ten months of collection. Meetings were also held between the CAPSiAD and UAi teams. The interviews with the care providers were carried out during the participant observation, in a confidential environment, following the principles of privacy, and audio recorded on a digital recorder, with the consent of the participants. Participation in the study was voluntary and preceded by information and clarification regarding the aims and procedures of the study, with signing of the consent form before beginning the interviews. The study was approved by the Research Ethics Committee of the Faculdade de Filosofia, Ciências e Letras de Ribeirão Preto - Universidade de São Paulo (CAAE n 72999417.0.0000.5407), considering all ethical aspects for the development of studies with human subjects, in compliance with Resolution 466/12.

The analysis of the interviews was performed using the thematic analysis technique, proposed by Clarke and Braun (2017), as a method to identify, analyze and report themes in the data. This analysis made it possible to organize and describe the data in a detailed way, assisting the interpretation. The researcher carried out a complete transcription of all the interviews and became familiar with the data, carrying out 4 repetitive readings of the interviews and the field diary. The interview coding was prepared by organizing 
the data in three columns, the first containing the interview in its entirety, the second containing a synthesis related to the aims of the study and the third with the groups of meanings identified in the interview. This process also included the help of a judge that coded three semi-structured interviews, which, when compared, were similar and consistent with the codings of the researcher. The potential themes were constructed by the first and third author after immersion in the codes and discussion. The notes in the field diary were used to help understand the data and support the creation of the themes.

From the participant observation and thematic analysis of the interviews, it was possible to identify that the care offered to the adolescent users seeks to create an environment with the function of providing physical and psychological resources, which were insufficient in other contexts due to social and family vulnerabilities. With that, three themes were elaborated that approach the institutional care, which are discussed using Winnicott's theory: (1) The setting: regarding the attention to basic needs and construction of routine; (2) The view: regarding empathy and expansion of perspectives; and (3) Aggressiveness: regarding new ways of relating. These themes address the importance of a structured, stable and welcoming environment to serve this population, as well as the need for an individualized and empathic view, to enable the expansion of the adolescents' perspectives and the construction of new ways of relating, based on dialogue and the management of aggressiveness for the affective development.

\section{Results and Discussion}

\section{Setting: attention to basic needs and construction of a routine}

This first theme concerns the dynamics of the organizational routine in which the adolescent is inserted. The theme was elaborated from the statements of the care providers extracted from the interviews, in which they described from the first moment of entering the institution, when it is necessary to give special attention to basic needs, until the structuring of a flexible routine and establishment of rules together with the adolescents.

It was found that, at first, when the adolescent is received, the institution serves as a protective place and the care provider needs to be aware of the adolescent's basic physiological needs, among them, food, sleep and hygiene (defined by Winnicott, 1964/1994, as handling). It is difficult to structure other activities until these basic needs are fulfilled. Maria (Higher Education, 40hrs) commented that this is the basis of the care: "We really try to have a view that is more focused on the boy and what his real need is at that moment. Today his need is just to sleep, so he goes to sleep, there is no point in saying: "Today the boy has to do all the activities". The boy spent the week awake".

In this sense, the institution would have the role of fulfilling the needs of these adolescents and adapting to them, so that the care provider is available to value the users' suffering and consider their expectations about the service through active listening (Ministério da Saúde, 2015).

According to Maria (Higher Education, 40hrs), the adolescents will often have their first contact with rules and limits in the institution: "Just being an adolescent is already very complicated and most of the adolescents we end up receiving never had someone in their family, or anyone else, who imposed a limit, who set rules". The care providers reported that flexibility is essential in structuring the routine, which is constructed gradually.

The gradual construction of rules, the physical limits of the institution and the affective relationship can serve as a form of container for the impulses of the children and adolescents received. This environmental protection is a form of care developed in an institutional environment that is based on containment, that 
is, the loan of real, affective and symbolic resources by the care providers that facilitate the development process (Pedroso, Lobato, \& Magalhães, 2016).

It is important to highlight that the establishment of rules is seen as something that should be constructed together with those received, without authoritarianism, in a horizontal relationship of care. The care providers reported that it is necessary to explain the reasons for the rules, negotiate and have flexibility in this construction, because when the adolescents comprehend and jointly construct the rules, they end up committing themselves to them.

The institution's environment could also have the function of internally organizing the child or adolescent received. For this, the care providers said that the Residential Care Unit must resemble a residential property and be predictable, that is, have a structured routine. The care providers reported that the aim of the UAi is to be a home for the adolescents, both physically, similar to a "family home", and emotionally with the establishment of affective bonds (holding).

These adaptations are in line with the concept of ambience, which, in health, is related to the treatment of the physical space, seen as a place for establishing welcoming, resolutive and humane interpersonal relationships, as well as a social and professional place. The territories are included in the humanization debate, considering the situations constructed in the spaces from the social, cultural and temporal contexts of the group relations that interact there (Ministério da Saúde, 2010). Therefore, it can be seen that the monitors and educators that accompany the daily activities of the children and adolescents, and are responsible for the closest care, have an almost maternal relationship of care and bonding, which is similar to the physical and affective support in the institutional environment. Rafael (Higher Education, 40hrs) commented:

So, the affection that most of the employees have is more than whether they like them or not, they end up being our family, we spend more time with them than, in my case, my daughter. And so, there are rare exceptions that we don't trust the boy, but the majority we like and treat as if they were our sons, both scolding them and giving them affection.

Close and affective care is essential to develop the bond and trust between the care providers and adolescents. This is a slow and costly process for the adolescents in situations of social vulnerability, since most have not experienced relationships of mutual trust and the environment with reliable family characteristics can more easily establish this bond (Novaes, Vilhena, Moreira, \& Zamora, 2009). For Sofia (Higher Education, 40hrs), the affective relationships constructed in the institution provide an important learning experience for those who have not had the opportunity to experience this type of relationship in other settings, including the family context: "I really like physical contact, I'm very emotional, so I kiss, I hug and they are sometimes scared because they don't have this. The vast majority don't have this, and I think that this affection is much more that sentimental part of the thing, I think that they learn a lot".

It is necessary for social and community interventions to develop actions to establish a reliable facilitating environment, capable of promoting the provision of care in a stable manner, based on handling and holding by the care providers, so that the adolescent can experience the setting in a new way (Junior \& Silva, 2018), feeling welcomed and safe.

\section{$\stackrel{\swarrow}{n}$

\section{View: empathy and broadening perspectives}

This theme seeks to demonstrate the importance of the care provider's individualized and trained view, so that it does not reproduce stigmas and social prejudices, but rather expands the possibilities of personal expression of the adolescents, allowing them to see themselves with new perspectives in life. Adolescents that arrive at the service have stories of great social suffering. They are individuals that have often been made invisible or viewed in a stigmatized and prejudiced way. The consequences of invisibility are disastrous for the 
construction of an identity, since existence is associated with being seen and recognized by the other (Novaes et al., 2009; Winnicott, 1967/1975). Helena (Higher Education, 30hrs) emphasized that it is essential not to reproduce a view based on common sense, but to have a professional and empathic view:

Treat them as all the same, as part of something that doesn't fit, to view them with prejudice. There are people that work here and say that they refuse to butter the bread, because they are not going to butter bread for criminals, which is a way that most people end up viewing the boys. To be here, you need to know that these boys are actually much more victims of society, because they didn't have opportunities and you need to view them as having the possibility to get out of that reality, to construct a new reality.

The subject's socialization process, when inserted in the condition of drug use, contributes to a funneling of the personal identity to the social roles existing in this context. However, these social roles are not innate characteristics of the users and can be transformed according to changes in their social relationships (Arenari \& Dutra, 2016). Maria (Higher Education, 40hrs) commented that this is a slow and gradual job, which requires an individualized and humanized view with knowledge of each person's history:

I think the fact that I really look at the boy, I think this is the work that we try to do, we don't find many people nowadays that are willing to do this work, looking more at the boy. Although most of them arrive with this situation of drug use, each uses differently, each has a different family, each has a different history.

The care providers have the function of seeing other facets of this individual and, with this, showing that there are other forms of reality and possibilities of life. "What thrills us as social beings, who need to interact in a supportive and harmonious way, is not that discipline understood as control of bodies, but emancipation, the expansion of the prospecting capacity: making the child and adolescent happen" (Ministério da Saúde, 2015, p.55, own translation)4. For Helena (Higher Education, 30hrs) this ethical attitude of the care provider in the care also enables the creation of bonds:

From the moment they enter, he is no longer Zé who is going to be beaten by the police, he is the guy that supports the São Paulo football team, who likes to eat pasta, who likes football, who doesn't like drumming. It is the individuality of each one that we manage to respect, looking and showing them how they can be this. They start to view each other in a different way, respect each other a little more and start to understand that, suddenly, it is not just this life they have for them. What ends up working is that they can understand that here they are seen as human beings with the right to access dignity and life.

The importance of this change in the care provider's view concerns the effect it can have on the way the adolescents see themselves. The care providers realize that the adolescents often see themselves as having no place, having no value. For Simone (Higher Education, 30hrs) it is the care provider's job to work with the adolescents' self-esteem and self-image: "To take care of this view that they have of themselves. They often do not allow themselves to be among people. One thing we care about is their view, showing that they are worthwhile, that they have a place". The construction of affective relationships and the establishment of a safe and familiar environment, which generates trust, contribute to the adolescents recovering their self-esteem and to elaborating previously experienced conflicts (Novaes et al., 2009), continuing their emotional development.

The activities and workshops proposed by the service only make sense to adolescents when they are able to see themselves in other ways, with new perspectives. This ability to understand the extent of their acts and analyze time, space and external reality is described by the Winnicottian framework as an achievement, a phase that provides the possibility of relationships with entire people (Junior \& Silva, 2018).

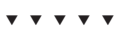

${ }^{4}$ In original: "O que nos vibra enquanto seres sociais, que precisam interagir de maneira solidária e harmônica, não é aquela disciplina entendida como controle dos corpos, mas sim a emancipação, a ampliação da capacidade de prospecção: fazer a criança e o adolescente acontecer" (Ministério da Saúde, 2015, p.55). 
An individualized view, affective relationships and the respect of the care providers can help the adolescents to see themselves in different ways and to construct the idea of respect, trust and empathy. From this, it is possible to develop a view of other people: "When I look I am seen, so I exist. I can now afford to look and see. I now look creatively and what I apperceive I also perceive" (Winnicott, 1967/1975, p.157, own translation)5. The reality, therefore, also starts to be perceived differently, there are possibilities to live an affective and safe encounter with the other, in which objects start to be presented and recognized with their real value.

\section{Aggressiveness: new ways of relating}

Aggressiveness expressed by children is a complex and multifactorial theme, covering environmental, constitutional and psychological aspects. It is a theme studied by several approaches and can be associated with the containment provided by the care figure (Basaglia \& Souza, 2015). Reports of aggressiveness were frequently made by the care providers interviewed and witnessed in the participant observation, as a behavioral characteristic of the majority of the adolescents received. The care providers comprehend that the children and adolescents have a history of aggressiveness in their ways of relating, which reflects the mistreatment, hostility and violence experienced on the street, in institutions and in the family.

According to Junior and Silva (2018), environmental deprivations can be extended to comprehend the losses in the possibility of being accepted by society, due to situations of social vulnerability. Helena (Higher Education, 30hrs) commented on how the adolescents reproduce a relationship model based on aggressiveness: "They arrive here with a lot of hostility that they receive on the street. They don't know how to relate to people in any other way and that's where a lot of bad words come from, a lot of fighting, a lot of conflict".

In this context, aggressiveness can also be understood as a symptom in the face of determined social suffering, not only associated with the experience of affective deprivation, but also with the early perception of socioeconomic inequalities and with seeking redress and justice (Chinalia et al., 2018). Social suffering is understood as the suffering that occurs in the context of oppression, discrimination and exclusion and causes feelings of helplessness, humiliation, guilt and injustice (Aiello-Vaisberg, 2017). For Simone (Higher Education, 30hrs) aggressiveness can be seen during the management of the suffering and very subtle and abstract work is necessary to be able to access the experiences and suffering of these users: "Here they are crying out for help, but they are also unable to experience their suffering and when I work on what they experience, their suffering, that's when they get into a very aggressive state because they can't get in touch with that".

From this, the care providers seek to enable the learning of alternative forms of relationship to construct an ethical basis in the relationships through dialogue and actions that encourage closer contact, whether physical or by establishing values such as mutual trust, that is, aspects that strengthen the bond between the care providers and the adolescents. These are issues that can be observed in the statement of Sofia (Higher Education, 40hrs):

We hear many stories from them of being mistreated in places that, by law, were there to assist them. We have this welcoming profile and are here to show that there is this other side of the coin. Sometimes, they come to us screaming, shouting, aggressive and how can we blame them for things they have not learned? Because, sometimes, mistreatment comes from the family itself, everything is in the scream, in the blow.

The setting can offer a new experience of conviviality to the adolescents, as they have experienced intense environmental failures harmful for the elaboration of conflicts and resumption of the emotional

5 In original: "Quando olho, sou visto; logo existo. Posso agora me permitir olhar e ver. Olho agora criativamente e sofro minha apercepção e também percebo” (Winnicott, 1967/1975, p.157). 
development. This environmental provision requires management capable of providing reliable and stable care, capable of giving the adolescents hope so that they start to believe in themselves and, consequently, in others, being able to construct a new perspective on life, in a creative and personal way (Junior \& Silva, 2018; Onocko-Campos, 2018). For this, the care providers demonstrate affection in the way they treat them, stating that it is possible to live together without this being based on aggression, with permanent and daily learning, as Sandra commented (Higher Education, 30hrs): "This affection, I think it makes a difference! Because we know that they are children that haven't been hugged, haven't had people say "Hi, how are you?". So, we can show that there is another way of living life, that we also achieve things with conversation, with respect, with courtesy".

Simone (Higher Education, 30hrs) emphasized that when the care provider approaches the adolescent differently, demonstrating attention, availability and recognition of the importance of their experiences and needs, this produces changes in their behavior. It allows them to express themselves without resorting to aggression, understanding that dialogue is an alternative to share concerns and difficulties:

It is that fight, dispute of who will speak louder, but when we come with a certain way, with affection to converse, they manage to understand, to explain why they are acting that way. That's what we try to teach them, they don't need to destroy everything to say that they miss their brother, they can sit with us to have a conversation and we see what can help (Simone, Higher Education, 30hrs).

There is a consensus among the care providers that tackling things head on promotes conflict and confrontation, with this not being indicated in the work with adolescents, since the aim is to develop new ways of communicating through dialogue. This attitude is in accordance with the techniques indicated by the strategic guide for the care for people with needs related to the consumption of alcohol and other drugs. This guide describes techniques for handling aggression, known as crisis escalation reduction techniques, through an understanding and comforting attitude with the use of conflict resolution methods (Ministério da Saúde, 2015). Fernanda (High School, 40hrs) reported this learning in the professional practice: "We can't confront them head on, in the beginning I used to confront them. And it's no use, because if you tackling things head on you lose your mind. You have to know how to talk to them".

The care providers demonstrated their awareness that reproducing the aggressive model based on a reaction to the adolescent's behavior does not promote changes in the relationship, since it only reiterates the model that the adolescents themselves are familiar with. Therefore, it is necessary to have alterity in the care to comprehend the outbursts as externalizations linked to emotional, psychological and family structures. One of the strategies found to avoid conflicts and develop ethical relationships was the alternation between monitors. Regarding this, Vitória (incomplete Elementary School, 12/36hrs) commented: "If he is just swearing at me, today I am working with Fernanda, 'Today the guy is swearing at me, so you will have to stay with him, because he can't look at me".

The group activities focus on the requirements related to social interaction perceived by the care providers. It was noted, through participant observation, that the groups had few individuals, worked with flexible themes and were divided by age and gender, which contributes to working with group specificities. Simone (Higher Education, 30hrs) indicated that these groups work with different forms of socialization: "I work with them a lot on social skills, constructing rules and having respect for each other, which are the biggest difficulties I see that appear in the UAi".

In the participant observation, it was also possible to accompany the reflection group, which aimed to enable and stimulate dialogue. It always occurred at the end of the day, when the routine situations of the service and the adolescents' lives were dealt with. At this moment, the monitors encouraged the adolescents to talk about the activities carried out, their difficulties, their experiences and feelings, looking for new ways to deal with conflicts that may have arisen throughout the day. This is a resource-construction strategy, 
which aims to prepare them for living in different social contexts, in facing reality (Mastelari, Pattarelli, \& Branco, 2018).

The statements of the care providers pointed to the cohesion of teamwork, an important aspect for establishing trust and bonding with the adolescents and family members. For Sandra (Higher Education, $30 \mathrm{hrs}$ ), when they realize that everyone is aware of each other's life context and strive together to provide care, they value and recognize the work developed:

I think it is important to strengthen everyone, one cares about the other, one relies upon the other, one wants the other to perform well. The boys understand that we all know what happens and we can provide that support. This happens with family members too [...] this trust that people have in us that we pass on to them.

Team cohesion is also essential to deal with professional suffering related to the emotional burden of the work. Therefore, the care provider also needs a support network to be able to deal with the aggressiveness and compose a mentalizing and reflective route of communication with the adolescent. Otherwise, they may end up merely following technical protocols to take refuge. In this respect, professional training is essential, especially for care providers working on the front line, that is, those that deal directly with the population served, such as the monitors and social educators, as they are the main people responsible for the close care relationship (Costa, Santos, Santos, \& Lima, 2018).

Effective care aims for the social transformation, emotional restructuring and citizen participation of these young people, based on attention to basic needs, creation of strong bonds of affection, as well as access to cultural goods, education, the labor market and artistic activities that encourage self-knowledge and creativity (Novaes et al., 2009). An individualized view of the users, as well as the understanding of aggressive manifestations as a reaction, allow the care provider to help adolescents to conduct themselves differently when frustrated, avoiding actions that put them at risk.

The construction of care aimed at children and adolescents with needs associated with drug use has several demands and complexities, with ready and quick formulas not being possible. The care relationship must be based on the joint construction of strategies that consider the singularities of the user's requirements and strengthen the bonds with services and territories (Ministério da Saúde, 2015). Fair, ethical and coherent interventions must consider the assumption that human beings are social beings that need supportive environments, in the family, community and social spheres, for their maturation (Chinalia et al., 2018).

\section{Final Considerations}

Children and adolescents that use drugs are still generally attended by organizations designed for adults, therefore it is necessary to contemplate forms of care that are specific to this population. The study aimed to comprehend, based on the Winnicottian theoretical framework, how a Child/Adolescent Residential Care Unit has been providing care to children and adolescents in situations of social vulnerability with needs arising from the use of drugs. This was carried out to obtain more support for the construction of public policies aimed at the care of adolescent drug users, considering that this is a current theme with recent and weakly structured public policies.

This study provides contributions to the comprehension of aspects that are important in reception services for children and adolescents that use drugs, using the Winnicottian theory regarding the stages of the emotional maturation process: holding, handling and object presenting, to comprehend the care relationships in an institutional environment. The study found that to ensure that the setting facilitates emotional development, attention should be paid to basic needs, such as food and hygiene, construction of a flexible routine, establishment of rules and limits together with the adolescent and assistance in dealing with aggressiveness. The construction of affective bonds was also shown to be fundamental in all the care 
relationship processes. These elements need to be considered in the construction of care policies and services for this specific population.

It is important to highlight that if the adolescents were not able to have sufficiently good experiences and the experience of holding in the family setting, they can receive the due care and affective support in another environment, allowing them to resume their emotional development, strengthen themselves and live in society. By welcoming and offering physical care and emotional support, the institutions allow the adolescent to find the other, feel seen in their needs and, accordingly, develop the security, confidence and self-esteem necessary for social interaction. In addition, professional qualification and strengthening of the articulation of the care network offered to adolescents is essential, as the affective provision in the institutional context ends up being temporary protective work, and other services must continue to provide these elements of care.

One of the limits of the study was to interview only the care providers of the service, without extending these interviews to the adolescents and family members. However, the participant observation carried out helped to broaden the comprehension regarding the studied theme and minimize this limitation. It is suggested that future studies evaluate how this care is continued after the adolescent leaves the Residential Care Unit.

\section{Contributors}

J. C. GOMES was responsible for the original article concept and design; collection, analysis and discussion of the data. F. K. T. MISHIMA-GOMES worked on the elaboration of the theoretical framework; review of the final version of the manuscript. C. M. CORRADI-WEBSTER was responsible for the project design, data analysis and writing process; reviewing and approving the final version of the manuscript.

\section{References}

Aiello-Vaisberg, T. M. J. (2017). Estilo clínico ser e fazer: resposta crítico-propositiva a despersonalização e sofrimento social. Boletim Academia Paulista de Psicologia, 37(92), 41-62. Recuperado de http://pepsic.bvsalud.org/scielo. php?script=sci_arttext\&pid=S1415-711X2017000100005\&lng=pt\&tIng=pt

Andrade, M. L., Mishima-Gomes, F. K. T., \& Barbieri, V. (2018). Children's grief and creativity: the experience of losing a sibling. Psico-USF, 23(1), 25-36. https://dx.doi.org/10.1590/1413-82712018230103

Arenari, B., \& Dutra, R. (2016). A construção social da condição de pessoa: premissas para romper o círculo vicioso de exclusão e uso problemático do crack. In J. Souza (Org.), Crack e exclusão social. Brasília: Ministério da Justiça e Cidadania, Secretaria Nacional de Política sobre Drogas.

Basaglia, A. E., \& Souza, M. A. (2015). Dificuldades de maternagem em um grupo de mães de crianças agressivas. Psicologia: Teoria e Prática, 17(1), 15-25. http://dx.doi.org/10.15348/1980-6906/psicologia.v17n1p15-25

Bastos, F. I. P. M., Vasconcellos, M. T. L. D., Boni, R. B., Reis, N. B. D., \& Coutinho, C. F. D. S. (2017). III Levantamento nacional sobre o uso de drogas pela população brasileira. Rio de Janeiro: Fiocruz. Recuperado de https://www.arca. fiocruz.br/handle/icict/34614

Chinalia, M., Assis, N., Visintin, C., \& Aiello-Vaisberg, T. (2018). Furtos de bagatelas e sofrimento social: uma interlocução com o pensamento Winnicottiano. Psicologia Revista, 27(1), 35-56. https://doi.org/10.23925/25943871.2018v27i1p35-56

Clarke, V., \& Braun, V. (2017). Thematic analysis. The Journal of Positive Psychology, 12(3), 297-298. https://doi.org/10 $1080 / 17439760.2016 .1262613$

Conceição, D. S., Andreoli, S. B., Esperidião, M. A., \& Santos, D. N. (2018). Atendimentos de crianças e adolescentes com transtornos por uso de substâncias psicoativas nos Centros de Atenção Psicossocial no Brasil, 2008-2012. Epidemiologia e Serviços de Saúde, 27(2). https://dx.doi.org/10.5123/s1679-49742018000200002

Costa, C. F., Santos, T. F., Santos, V. S., \& Lima, L. A. G. (2018). Entre a instituição e o lar: uma odisseia com educadores. Revista Pesquisas e Práticas Psicossociais, 13(1), 1-15. Recuperado de http://www.seer.ufsj.edu.br/index.php/revista_ppp/ article/view/2838 
Dunne, T., Bishop, L., Avery, S., \& Darcy, S. (2017). A review of effective youth engagement strategies for mental health and substance use interventions. Journal of Adolescent Health, 60(5), 487-512. https://doi.org/10.1016/j. jadohealth.2016.11.019

Jimenez, L., Adorno, R., \& Marques, V. R. (2018). Drogas pra que te quero? Drogadição e adolescência na voz dos socioeducadores. Psicologia: Teoria e Pesquisa, 34, e34412. https://dx.doi.org/10.1590/0102.3772e34412

Junior, A. A. P., \& Silva, S. M. (2018). O Adolescente em conflito com a lei e a tendência antissocial: compreensão e intervenção à luz da psicanálise Winnicottiana. Revista Brasileira Adolescência e Conflitualidade, 1(17), 82-89. http:// dx.doi.org/10.17921/2176-5626.n17p82-89

Mastelari, T. B., Pattarelli, S., C., \& Branco, P. M. C. (2018). Contribuições Winnicottianas para uma clínica psicanalítica diferenciada. Revista Terra e Cultura: Cadernos de Ensino e Pesquisa, 30(59), 129-131. Recuperado de http://periodicos. unifil.br/index.php/Revistateste/article/view/155

Ministério da Saúde (Brasil). (2010). Ambiência. Brasília: Autor. Recuperado de http://bvsms.saude.gov.br/bvs/publicacoes/ ambiencia_2ed.pdf

Ministério da Saúde (Brasil). (2011). Portaria n 3.088, de 23 de dezembro de 2011. Institui a Rede de Atenção Psicossocial para pessoas com sofrimento ou transtorno mental e com necessidades decorrentes do uso de crack, álcool e outras drogas, no âmbito do Sistema Único de Saúde (SUS). Diário Oficial da União, Brasília: Autor. Recuperado de http:// bvsms.saude.gov.br/bvs/saudelegis/gm/2011/prt3088_23_12_2011_rep.html

Ministério da Saúde (Brasil). (2012). Portaria no 121, de 25 de janeiro de 2012. Institui a Unidade de Acolhimento para pessoas com necessidades decorrentes do uso de Crack, Álcool e Outras Drogas (Unidade de Acolhimento), no componente de atenção residencial de caráter transitório da Rede de Atenção Psicossocial. Diário Oficial da União. Brasília: Autor. Recuperado de http://www.saude.gov.br/images/pdf/2015/marco/10/PORTARIA-121-25-JANEIRO-2012.pdf

Ministério da Saúde (Brasil). (2015). Guia estratégico para o cuidado de pessoas com necessidades relacionadas ao consumo de álcool e outras drogas. Brasília: Autor. Recuperado de https://repositorio.observatoriodocuidado.org/ handle/handle/1275

Mishima-Gomes, F. K. T. (2011). Obesidade feminina: considerações a partir do psicodiagnóstico interventivo (Tese de doutorado não-publicada). Universidade de São Paulo. http://dx.doi.org/10.11606/T.59.2011.tde-11082011-163936

Mishima-Gomes, F. K. T., Dezan, S. Z., \& Barbieri, V. (2014). "Não pode!" : a função paterna e a obesidade infantil. Psico, 45(2), 176-186. http://dx.doi.org/10.15448/1980-8623.2014.2.13307

Novaes, J. D. V., Vilhena, J., Moreira, A. C. G., \& Zamora, M. H. (2009). As crianças que ninguém quer: a clínica psicanalítica em uma instituição de portas abertas. Arquivos Brasileiros de Psicologia, 61(1), 16-29. Recuperado de http://pepsic. bvsalud.org/scielo.php?script=sci_arttext\&pid=S1809-52672009000100003\&lng=pt\&tlng=pt

Onocko-Campos, R. (2018). Comportamento antissocial nos jovens com sequela da privação: contribuições da clínica Winnicottiana para as políticas públicas. Interface, 22(67), 1091-1098. https://dx.doi.org/10.1590/1807-57622017.0315

Pedroso, J. S., Lobato, C. P., \& Magalhães, C. M. C. (2016). Brincar e realidade: verbalizações de crianças em situação de acolhimento institucional. Psicologia em Estudo, 21(4), 711-721. Recuperado https://www.redalyc.org/ pdf/2871/287149565016.pdf

Russell, C., Neufeld, M., Sabioni, P., Varatharajan, T., Ali, F., Miles, S., ... Rehm, J. (2019). Assessing service and treatment needs and barriers of youth who use illicit and non-medical prescription drugs in Northern Ontario, Canada. Plos One, 14(12), e0225548. https://doi.org/10.1371/journal.pone.0225548

Winnicott, D. W. (1975). O papel de espelho da mãe e da família no desenvolvimento infantil. In D. Winnicott (Org.), $O$ brincar e a realidade (pp.153-162). Rio de Janeiro: Imago (Originalmente publicado em 1967).

Winnicott, D. W. (1983). Da dependência a independência no desenvolvimento do indivíduo. In D. W. Winnicott (Org.), O ambiente e os processos de maturação (pp.79-87). Porto Alegre: Artes Médicas (Originalmente publicado em 1963).

Winnicott, D. W. (1994). A importância do setting no encontro com a regressão na psicanálise. In C. Winnicott, R. Sheperd, \& M. Davis (Orgs.), Explorações psicanalíticas: D. W. Winnicott (pp.77-81). Porto Alegre: Artmed (Originalmente publicado em 1964).

Zimerman, D. E. (2009). Fundamentos psicanalíticos: teoria, técnica, clínica uma abordagem didática. Porto Alegre: Artmed.

Received: September 27, 2019

Final version: July 17, 2020

12 Approved: August 31, 2020 